\title{
ANALISA PERAN MODERASI AUDIT TENURE DALAM HUBUNGAN ANTARA ORIENTASI KESALAHAN INDIVIDU DAN IKLIM KESALAHAN ORGANISASI TERHADAP PENANGANAN KESALAHAN PADA AUDITOR INSPEKTORAT KEMENTERIAN DI INDONESIA
}

\author{
Danang Mintoyuwono \\ danangmintoyuwono@gmail.com \\ Fakultas Ekonomi UPN "Veteran” Jakarta \\ Jl. R.S. Fatmawati Pondok Labu, Jakarta Selatan - 12450
}

\begin{abstract}
ABSTRACK
The auditor's error handling strategy as auditor behavior after detecting an auditee's error has significant impact on repeat error finding especially unintentional errors. The purpose of this study was to investigate factor determining error management as auditor error handling strategy from organizational and individual aspect also investigate moderation role of audit tenure. 103 government auditor involve in this study as respondent collecting via convenience sampling, with linear regression and interaction moderated regression as data analysis method. Result of this study shows both organizations' error climate and person's individual error orientation has positive significant impact on error management as auditor error handling strategy otherwise moderation of audit tenure have no empirical evidence. Thus error management is conducting by auditor in an open climate organization with greater person's individual error orientation.
\end{abstract}

Keyword : error handling strategy, organizations' error climate, person's individual error orientation, audit tenure, unintentional errors

\section{PENDAHULUAN}

\section{Latar Belakang Penelitian}

Auditor eksternal dalam menjalankan fungsi kontrol kualitas dalam organisasi harus mampu memberikan respon yang baik saat menemukan kesalahan (Gold et al, 2011). Salah satu masalah utama yang sering dihadapi oleh auditor eksternal adalah ditemukannya kesalahan berulang. Kesalahan berulang dalam konotasi audit negatif berarti mengulangi kesalahan sistematis pada transaksi atau akun yang sama atau mengulangi kelemahan material yang sama dalam bidang manajemen keuangan dan proses pelaporan, metodologi akrual akhir tahun, atau kontrol lingkungan secara umum (BPK, 2007), salah satu penyebab terjadinya kesalahan berulang adalah kurang optimalnya strategi perilaku auditor akan tindak lanjut temuan kesalahan dari auditee, atau secara spesifik terkait konsep strategi penanganan kesalahan (Gronewold dan Donle, 2007).

Penelitian ini akan memfokuskan pada strategi penanganan kesalahan (error handling) yaitu cara dan tindak lanjut yang dilakukan auditor saat 
berhadapan dengan kesalahan auditee (Gronewold dan Donle,2007). Berdasarkan konsep manajemen kesalahan perilaku auditor mengenai tindak lanjut temuan kesalahan dari auditee, akan mempengaruhi penerimaan hasil dan implementasi dari rekomendasi yang diberikan auditor terhadap auditee (Gronewold dan Donle, 2007). Oleh karena itu guna mencapai tujuan, dimana auditor eksternal sebagai agen pengawasan diharapkan mampu mendorong terwujudnya good governance dan mendukung operasional organisasi yang efektif, efisien, transparan, akuntabel serta bersih, maka pilihan strategi rekomendasi yang dilakukan oleh auditor akan berdampak pada output audit tahun selajutnya (i.e pengulangan kesalahan yang sama).

Mekanisme

penanganan

kesalahan terdiri dari pilihan strategi mencegah kesalahan (error preventing) dan manajemen kesalahan (error management), dimana hasil penelitian terdahulu pada penanganan kesalahan menunjukan bahwa strategi yang lebih condong pada manajemen kesalahan mampu mengurangi kesalahan sistematis yang sama (Gronewold dan Donle, 2010). Strategi manajemen kesalahan diimplementasikan auditor melalui perilaku paska mendeteksi kesalahan auditee dengan menyalurkan pengetahuan yang dimilikinya ke auditee dan department yang sedang di audit. Tujuan utama audit adalah pengembangan organisasional dan jika terdapat kesalahan yang dideteksi, auditor akan belajar dari kesalahan tersebut, dan umpan balik yang dominan adalah dalam bentuk oral.
Sebaliknya strategi mencegah kesalahan adalah evaluasi kesalahan secara negatif oleh auditor, tujuan utama audit adalah mendeteksi sebanyak mungkin kesalahan material, mendokumentasikannya lalu menghapuskannya dan umpan balik dalam bentuk tulisan (Gronewold dan Donle,2007). Dua bentuk strategi tersebut dalam konteks akuntansi hal ini merupakan bentuk monitoring, dan pengendalian yang dilakukan oleh auditor eksternal guna mencegah proses pelaporan yang kurang wajar. Dimana pemeriksa harus merencanakan dan melaksanakan prosedur pemeriksaan untuk mengembangkan unsur-unsur temuan pemeriksaan, Temuan pemeriksaan, seperti kurang memadainya pengendalian intern, penyimpangan dari ketentuan peraturan (GAAP), kecurangan, serta ketidakpatutan biasanya terdiri dari unsur kondisi, kriteria, sebab dan akibat. Auditor sebagai manusia tidak lepas dari kekeliruan, temuan kesalahan oleh auditor pada proses evaluasi audit adalah hal umum yang sering terjadi baik pada audit umum maupun sektor publik (Gold et al, 2011) akan tetapi yang terpenting adalah proses untuk memperbaiki kesalahan tersebut yang terkait dengan perilaku auditor.

Hasil penelitian terdahulu tentang faktor yang dapat mendorong auditor untuk menerapkan strategi manajemen kesalahan pada temuan audit adalah atribut personal dari individual auditor terhadap kesalahan dan norma-norma organisasi atas kesalahan secara spesifik adalah variable (orientasi kesalahan auditor (individual error orientation) dan 
iklim kesalahan organisasi (organizational error climate) (Gold, et al 2011, Gronewold dan Donle, 2007 dan 2010). Selain dua faktor tersebut berdasarkan konteks literature kualitas audit, tenure atau lama hubungan antara auditor dan auditee juga patut dipertimbangkan dalam memprediksi strategi penanganan kesalahan audit. Temuan penelitian terdahulu menunjukan spesialitasi auditor dan tenure akan dapat meningkatkan kualitas audit (Almutairi et al, 2009). Manajer audit dan auditor senior akan lebih baik dalam mendeteksi kesalahan saat melakukan tugas audit di organisasi yang telah dikenal, dan semakin lama berhubungan maka kemampuan untuk menginterpretasikan misstatement dan pola yang tidak lengkap menjadi semakin baik.

Berdasarkan pemaparan tersebut maka penelitian ini bertujuan untuk memprediksi faktor yang dapat menentukan pemilihan strategi penanganan kesalahan pada temuan audit yang mengarah pada manajemen kesalahan, yaitu variable (orientasi kesalahan auditor (individual error orientation) dan iklim kesalahan organisasi (organizational error climate) (Gold, et al 2011, Gronewold dan Donle,2007 dan 2010) dan memperjelas hubungan konseptual tersebut dengan auditor tenure. Dimana tingkat lama berhubungan auditor dengan organisasi yang di audit akan dapat membedakan tinggi rendahnya efek orientasi kesalahan auditor dalam model penerapan strategi manajemen kesalahan, sebab konstruk nilai individu adalah sebuah konstruk persepsi yang dapat memiliki bentuk berbeda dalam proses pengolahan informasi sehingga lama hubungan atau auditor tenure akan memainkan peran penting dalam proses output keputusan. Maka lama hubungan auditor sebagai variabel pemoderasi, antara orientasi kesalahan individu dan strategi penangangan kesalahan.

\section{Perumusan Masalah}

Berdasarkan pada uraian diatas maka rumusan masalah dalam penelitian ini adalah sebagai berikut:

1. Apakah iklim kesalahan organisasi berpengaruh signifikan terhadap bentuk penanganan kesalahan yang dilakukan oleh auditor?

2. Apakah orientasi kesalahan individu berpengaruh signifikan terhadap bentuk penanganan kesalahan yang dilakukan oleh auditor?

3. Apakah lama audit memoderasi pengaruh orientasi kesalahan individu terhadap bentuk penanganan kesalahan yang dilakukan oleh auditor?

\section{TINJAUAN PUSTAKA DAN PENGEMBANGAN HIPOTESIS Kesalahan dan proses penanganan kesalahan}

Berdasarkan konteks penelitian audit, kesalahan adalah perbedaan antara nilai yang dibukukan dengan nilai yang benar atau sebenarnya. Bagi auditor merupakan tugas penting untuk mendeteksi kesalahan atau deviasi dalam masalah atau tugas audit yang dilaksanakan (Gronewold dan Donle, 2007). Kesalahan dapat diklasifikasikan sebagai kesalahan disengaja atau tidak disengaja, juga 
dapat dilihat dari sisi kesalahan material atau immaterial. Secara lebih spesifik kesalahan disini adalah adanya perbedaan dari status aktual (status nyata) dengan status ideal (status sebenarnya). Pada penelitian ini tidak akan melihat dari sisi kesalahan disengaja sebab tindakan pada saat menangani fraud berbeda dengan kondisi kesalahan tidak disengaja.

$\begin{array}{rcr}\text { Disisi } & \text { lain definisi } \\ \text { penanganan } & \text { dari }\end{array}$ handling) adalah cara yang dilakukan auditor saat berhadapan dengan kesalahan auditee (Gronewold dan Donle,2007). Konseksuensinya strategi penanganan kesalahan yang berbeda akan memberikan dampak berbeda terhadap proses pembelajaran dan kinerja baik bagi organisasi maupun individu. Proses penanganan kesalahan juga meliputi penjelasan dan upaya menghilangkan kesalahan. Mekanisme penanganan kesalahan terdiri dari pilihan strategi mencegah keselahan (error preventing) dan manajemen kesalahan (error management), Dimana dua bentuk strategi ini diimplementasikan dengan dua umpan balik yang berbeda yaitu umpan balik dalam bentuk tulisan dan oral (Gronewold dan Donle, 2007)

Strategi mencegah kesalahan adalah bentuk penggunaan strategi yang merujuk pada evaluasi kesalahan secara negatif oleh auditor dimana tujuan utama dari audit adalah mendeteksi sebanyak mungkin kesalahan material, mendokumentasikannya untuk kemudian menghapuskannya. Dengan strategi ini kesalahan kedepan dapat dihindari dengan cara melakukan pencegahan. Setelah mendeteksi kesalahan, auditor yang mengikuti strategi ini berkonsentrasi dalam mengindentifikasi individu-individu yang bertangung jawab terhadap kesalahan tersebut. Rekomendasi ditentukan oleh auditor itu sendiri tanpa berkoordinasi dengan auditee. Bentuk umpan balik yang paling banyak digunakan adalah laporan tertulis yang berisi temuan negatif dari audit, tanpa mencantumkan tanggapan atau penjelasan dari auditee.

Sebaliknya strategi manajemen kesalahan adalah bentuk penggunaan strategi yang merujuk pada pertimbangan auditor yang memandang diri mereka sebagai spesialis yang dapat menyalurkan pengetahuan yang dimilikinya ke auditee dan department yang sedang di audit. Tujuan utama audit adalah pengembangan organisasional dan jika terdapat kesalahan yang dideteksi, auditor akan belajar dari kesalahan tersebut. Dengan strategi ini kesalahan kedepan dapat dihindari dengan cara belajar. Setelah mendeteksi kesalahan, auditor yang mengikuti strategi ini tidak berkonsentrasi untuk mengindentifikasi individu-individu yang bertangung jawab terhadap kesalahan tersebut akan tetapi dengan menganalisa penyebab sistematis dari kesalahan tersebut. Melalui upaya yang diberikan auditor berusaha untuk menciptakan kompetensi penghindaran kesalahan ke auditee, sehingga auditee mampu untuk mendeteksi dan memperbaiki kesalahannya sendiri dan menghindari pengulangan kesalahan tersebut dimasa yang akan datang. Disini auditor berupaya untuk terbuka 
terhadap kesalahan. Bentuk umpan balik yang banyak diberikan dalam strategi ini adalah umpan balik oral dengan individu yang terlibat dalam system. Auditor tertarik dengan sudut pandang auditee dan mempertimbangkan opini auditee dalam membuat penilaian. Laporan yang dibuat oleh auditor melalui evaluasi organisasi, meliputi aspek positif dan negatif. Observasi dan pendapat auditee juga didokumentasikan dalam laporan.

Kedua bentuk strategi yang diungkapkan diatas merupakan dua bentuk perilaku yang sangat berbeda jauh. Perilaku sebenarnya dari auditor biasanya merupakan gabungan dari dua aspek strategi tersebut, akan tetapi tetap auditor memiliki kecenderungan kesalah satu arah dari strategi tersebut pada auditor tertentu di waktu tertentu.

\section{Pengaruh Iklim kesalahan organisasi terhadap penanganan kesalahan}

Iklim kesalahan organisasi adalah aspek spesifik dari iklim organisasi. Hal ini mencangkup kepercayaan, sikap dan norma mengenai kesalahan yang ada dalam organisasi, dan cara bagaimana mengatasi kesalahan dalam organiasi tersebut (Van Dyck 2000, 106 dalam Gronewold dan Donle,2007). Dalam iklim kesalahan organiasi juga terdapat dua bentuk orientasi organisasi terhadap kesalahan yaitu penghindaran kesalahan dan manajemen kesalahan. Suatu organisasi dapat dikategorikan berdasarkan level kemampuan manajemen kesalahan (Gold et al, 2011). Organisasi yang lebih cenderung mengarah pada perilaku yang mengutamakan pencegahan kesalahan akan mengarah pada strategi penanganan kesalahan dalam bentuk pencegahan. Sebaliknya organisasi yang mendukung perilaku manajemen kesalahan akan mengarah pada upaya pembelajaran dari kesalahan. Beberapa hasil penelitian menunjukan bahwa organisasi dengan orientasi manajemen kesalahan akan menghasilkan prestasi dan kinerja subjektif yang lebih dibanding organisasi dengan budaya pencegahan kesalahan (Edmondson 1996; Göbel and Frese 1999, 101 dalam Gronewold dan Donle,2007).

Organisasi dengan manajemen kesalahan yang tinggi atau disebut juga iklim terbuka (open climate) adalah organisasi yang dibangun berdasarkan kepercayaan bahwa kesalahan akan terjadi meskipun individu-individu telah berupaya maksimal dalam menjalankan tugas. Oleh karena itu organisasi ini akan terbuka dengan berbagai cara untuk mengatasi kesalahan tersebut. Pandangan ini menyatakan bahwa organisasi akan menerima kenyataan dan mempersiapkan rencana untuk mengambil manfaat dari kesalahan yang terungkap untuk meningkatkan proses (Gold et al, 2011).

Organisasi dengan iklim yang terbuka memiliki beberapa cirri-ciri yaitu membantu saat kesalahan terjadi, melakukan analisis atas kesalahan yang terjadi, komunikasi terbuka tentang kesalahan dengan orang lain dalam tim dan perhatian pada upaya koreksi kesalahan seperti membantu orang lain setelah menemukan kesalahan melalui analisis kesalahan dan penyebab potensial kesalahan tersebut (Gronewold dan Donle,2007, dan Gold et al, 2011 ). 
Iklim organisasi yang terbuka pada organisasi non-audit akan membantu pengembangan organisasi melalui pemahaman kesalahan, penyebab kesalahan, dan cara yang efektif untuk menangani kesalahan diantara anggota organisasi salah satunya melalui laporan dan komunikasi tentang kesalahan. Oleh karena itu iklim tersebut dapat diduga sangat bermanfaat dalam meningkatkan kulaitas dan kinerja organisasi (Gold et al, 2010).

Berdasarkan beberapa penelitian baik dari sisi psikologis maupun organiasi audit menunjukan bahwa bentuk organisasi yang ideal adalah organisasi dengan iklim terbuka atau dengan kata lain organisasi yang sangat mengedepankan manajemen kesalahan (Gronewold dan Donle,2007, Gold et al, 2010 dan Gold et al, 2011).

Organisasi yang menciptakan budaya dimana karyawan diminta untuk belajar tentang segala sesuatu kesalahan baik dari diri sendiri maupun orang lain, sehingga memiliki pemahaman bagaimana suatu tindakan berpengaruh terhadap orang lain adalah bentuk ideal implementasi pembelajaran dari kesalahan. Salah satu manfaat pembelajaran organisasi (organizational learning) adalah untuk menurunkan peluang terjadinya pengulangan kesalahan (ADB, 2008).

Komponen dalam iklim kesalahan organisasi yang mengarah pada manajemen kesalahan salah satunya adalah analisis terhadap kesalahan dan penyebab potensial kesalahan (Gold et al, 2011). Bentuk implementasinya adalah adanya budaya yang terbuka bahwa seseorang dapat belajar dari kesalahan, adanya kepercayaan untuk menganalisa kesalahan, serta upaya bersama untuk menganalisa kesalahan (Gronewold dan Donle,2007). Hal ini menunjukan terjadi proses akumulasi pengalaman yang dapat mendorong seseorang untuk menciptakan perhatian terhadap kesalahan yang dibuat, dan tidak secara cepat memutuskan kesalahan sebagai suatu bentuk hukuman (Gronewold dan Donle, 2007).

Lebih jauh ciri-ciri organisasi yang berhasil melakukan transfer pengetahuan antar anggota adalah organisasi yang individu-individu merasa memiliki kecerdasan bersama, organisasi yang menyakini bahwa tetap terdapat peluang untuk terjadinya kesalahan meskipun pekerjaan telah dilaksanakan dengan baik. Kemudian organisasi yang karyawan diminta untuk belajar tentang segala sesuatu bentuk kesalahan yang dibuat, serta organisasi yang individu-individu dapat dengan bebas meminta pendapat dan bantuan orang lain untuk mengatasi kesalahan yang terjadi, dimana tidak lagi terjadi kerahasiaan atau subjeksubjek yang tidak didiskusikan (Gronewold dan Donle,2007) konsekuensi dari terciptanya kepercayaan dan nilai-nilai tersebut adalah orang akan semakin menerima dan terbuka terhadap kesalahan, yang mampu menciptakan sikap positif atas kesalahan yang diterjemahkan dalam perilaku auditor yang berusaha untuk mengatasi dan belajar dari temuan kesalahan dari klien.

Komunikasi dalam organisasi dengan iklim kesalahan terbuka akan memiliki ciri yaitu kesalahan didiskusikan secara terbuka, adanya rasa saling mengingatkan tentang 
peluang terjadinya kesalahan, serta mengutamakan diskusi tentang pentingya pembahasan kesalahan dan solusinya(Gronewold dan Donle,2007), dimana dengan adanya ciri-ciri organsiasi diatas maka akan mendorong auditor untuk menerapkan strategi manajemen kesalahan sebagai perilaku dalam berhubungan dengan auditee yang konsekuensinya menciptakan penganganan kesalahan melalui bentuk komunikasi oral, serta berupaya meminta sudut pandang audtee agar menghasilakan informasi yang terinci secara jelas dalam bentuk rekomendasi yang detail dan kongkrit dan komunikasi yang tepat sehingga subjek audit akan dapat mencerna rekomendasi yang diberikan oleh auditor eksternal yang dampaknya akan mampu ditindaklanjuti auditee dengan upaya koreksi hasil dari rekomendasi auditor. Sehingga dapat dikatakan bahwa semakin terbuka iklim kesalahan organisasi akan mendorong pada bentuk perilaku penanganan kesalahan dengan manajemen kesalahan disbanding menggunakan strategi pencegahan kesalahan. Hasil ini didukung temuan empiris yang menunjukan bahwa iklim kesalahan organisasi yang mengarah pada iklim terbuka akan berpengaruh positif terhadap tingkat penggunaan strategi penangangan kesalahan dengan strategi manajemen kesalahan (Gronewold dan Donle,2011). Oleh karena itu dapat ditarik suatu hipotesa bahwa :

H1 : Iklim kesalahan organiasasi berpengaruh positif signifikan terhadap bentuk penanganan kesalahan yang dilakukan oleh auditor

\section{Pengaruh Orientasi kesalahan individu terhadap penanganan kesalahan}

Orientasi kesalahan individu (individu error orientation) adalah sikap individu terhadap kesalahan yang dibuat oleh dirinya sendiri dan cara menangani kesalahan tersebut (Gronewold dan Donle, 2007). Orientasi kesalahan bergantung pada sejauh mana kesalahan pribadi dievaluasi secara negatif dan tingkat sejauh mana suatu kesalahan berusaha untuk dihindari. Serta juga seberapa jauh seorang individu ingin untuk berdialog tentang kesalahan yang dibuat, upaya untuk mengevaluasi kesalahan yang terjadi serta bagaimana cara menangani kesalahan dan upaya untuk belajar dari kesalahan. Orang dengan orientasi menghindari kesalahan, secara umum akan memandang kesalahan sebagai hal negatif dan secara aktif menghindari kesalahan tersebut. Jika kesalahan tetap terjadi, individu tersebut menutupi kesalahan dan tidak mau membuang waktu untuk menganalisa penyebab kesalahan. Individu ini juga memiliki kompetensi yang rendah dalam menghadapi kesalahan dan tidak akan focus untuk belajar dari kesalahan.

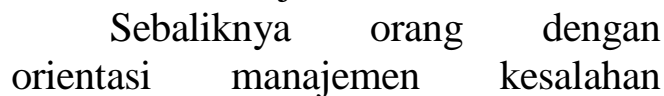
mengangap kesalahan sebagai peluang untuk belajar guna meningkatkan rutinitas kerja. Auditor dengan orientasi ini beranggapan bahwa kesalahan juga tetap mungkin terjadi meskipun pekerjaan telah dilakukan secara seksama dan dengan berhatihati. Auditor akan secara terbuka melakukan komunikasi tentang kesalahan yang dilakukannya adan 
secara aktif berusaha memperbaiki kesalahan. Orientasi kesalahan individu dapat diukur dengan indicator-indikator yaitu komunikasi mengenai kesalahan, pembelajaran dari kesalahan, analisis kesalahan yang terjadi dan kompentensi mengatasi kesalahan.

Seperti yang telah diungkapakan inisiatif untuk menciptakan pembelajaran kepada auditee dapat dilakukan oleh auditor. Salah satu implementasi dari bentuk pembelajaran kepada auditee adalah dengan bentuk strategi penanganan kesalahan dengan manajemen kesalahan. Untuk mencapai penerapan strategi manajemen kesalahan sebagai perilaku auditor dipengaruhi oleh tidak hanya factor situasional (iklim kesalahan) akan tetapi juga karakteristik individu terhadap kesalahan (Gronewold dan Donle, 2007).

Upaya untuk menghasilkan auditor yang secara sadar tidak langsung mengambil strategi yang memandang kesalahan secara negatif melalui strategi pencegahan kesalahan dan berusaha untuk mencari subjek pelaku kesalahan yang kemudian menerapkan hukuman terhadap individu di audite. Sebaliknya auditor akan berupaya terbuka mendapatkan umpan balik dan tidak berkonsentrasi untuk mengindentifikasi individuindividu yang bertangung jawab terhadap kesalahan tersebut akan tetapi dengan menganalisa penyebab sistematis dari kesalahan tersebut. Sehingga auditee mampu untuk mendeteksi dan memperbaiki kesalahannya sendiri dan menghindari pengulangan kesalahan tersebut dimasa yang akan datang yang adalah dengan membentuk perilaku subjektif individu auditor yang memandang masalah sebagai hal positif dan sebagai peluang pembelajaran kedepan (Gronewold dan Donle,2007). Auditor dengan sikap positif terhadap kesalahan serta terbuka atas kesalahan pribadi adalah auditor yang mampu menerapkan perilaku manajemen kesalahan. Hasil ini didukung temuan empiris yang menunjukan bahwa orientasi kesalahan individu akan berpengaruh positif terhadap tingkat penggunaan strategi penangangan kesalahan dengan strategi manajemen kesalahan (Gronewold dan Donle,2011). Oleh karena itu dapat ditarik suatu hipotesa bahwa :

$\mathrm{H} 2$ : Orientasi kesalahan individu berpengaruh positif signifikan terhadap bentuk penanganan kesalahan yang dilakukan oleh auditor

\section{Peran moderasi audit tenure dalam hubungan Orientasi kesalahan individu terhadap penanganan kesalahan}

Audit tenure, atau lama berhubungan antara auditor dengan lembaga atau organisasi yang di audit adalah faktor penting dalam menjembatani hubungan Orientasi kesalahan individu terhadap pilihan strategi manejemen kesalahan. tenure atau lama hubungan antara auditor dan auditee juga patut dipertimbangkan dalam memprediksi strategi penanganan kesalahan audit. Temuan penelitian terdahulu menunjukan spesialisasi auditor dan tenure akan dapat meningkatkan kualitas audit (Almutairi et al, 2009). Manajer audit dan auditor senior akan lebih baik dalam mendeteksi kesalahan saat melakukan tugas audit di organisasi 
yang telah dikenal, dan semakin lama berhubungan maka kemampuan untuk menginterpretasikan misstatement dan pola yang tidak lengkap menjadi semakin baik.

Nilai adalah sebuah konstruk persepsi dan Orientasi kesalahan individu adalah terkait dengan nilai. Oleh karena itu penilaian terhadap kesalahan yang akan mempengaruhi strategi penanganan kesalahan, juga dipengaruhi oleh bagimana cara dalam proses pembuatan keputusan, jika auditor membentuk keputusan berdasarkan proses terstruktur dari atribut-atribut intrinsic temuan audit dan auditor cenderung memiliki orientasi manajemen kesalahan yang tinggi maka auditor akan pada awalnya akan berusaha mendeteksi sebanyak mungkin kesalahan dan kemudian seiring waktu baru berinsiatif untuk menciptakan pembelajaran dan mengkomunikasikan kesalahan kepada auditee. Sehingga hubungan antara dan Orientasi kesalahan individu dengan pemilihan strategi manajemen kesalahan akan lebih tinggi pada auditor dengan tingkat hubungan yang lebih lama dibanding pada auditor yang jarang berhubungan dengan auditee. Oleh karena itu dapat ditarik suatu hipotesa bahwa :

H3 : Pengaruh positif Orientasi kesalahan individu terhadap bentuk penanganan manajemen kesalahan akan lebih tinggi pada auditor yang berhubungan lebih lama dengan auditee dibanding yang jarang berhubungan dengan auditee.

\section{Pengukuran dan Definisi Operasional Variabel}

Model penelitian disajikan pada Gambar. 1. Model dapat dijelaskan bahwa Iklim kesalahan organisasi dan Orientasi kesalahan individu akan berpengaruh pada strategi penanganan kesalahan serta auditor tenure akan memoderasi pengaruh orientasi kesalahan individu terhadap penanganan kesalahan.

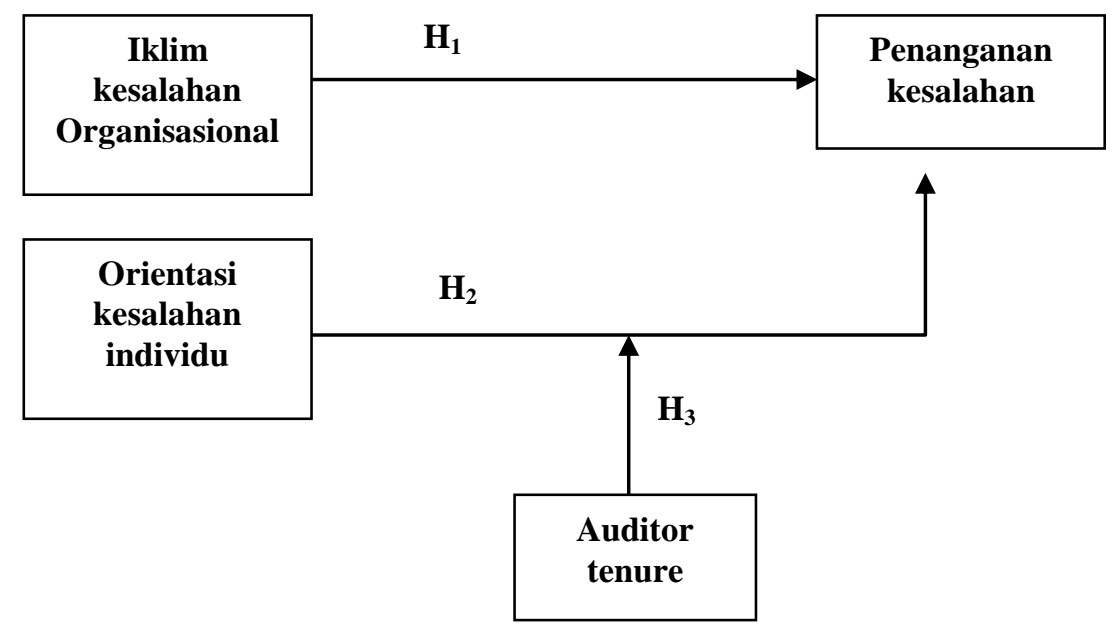

Gambar. 1 Model penelitian dan Hipotesa 
Berdasarkan gambar 1 bahwa Iklim kesalahan organisasi terutama iklim yang mengarah pada manajemen kesalahan akan menciptakan proses aktualisasi pengetahuan masing masing auditor, dimana dengan proses belajar dari pengalaman atas kesalahan dan komunikasi kesalahan yang baik dalam organisasi akan merangsang auditor mengabil langkah penanganan kesalahan dengan manajemen kesalahan. Serta sikap individu yang terbuka dan mampu mengkomunikasikan kesalahannya sendiri, memiliki keinginan untuk belajar dari kesalahan dan berusaha memperbaiki kesalahan adalah bentuk sikap yang dapat mendorong pada perilaku penanganan kesalahan dengan manajemen kesalahan. Lama hubungan auditor dengan organisasi yang diaudit akan mempengaruhi hubungan antara orientasi kesalahan individu terhadap bentuk penanganan dengan manajemen kesalahan.

\section{METODE PENELITIAN Instrumen penelitian}

Penelitian ini menggunakan ítem-item pengukuran yang diambil dari penelitian sebelumnya. Iklim kesalahan organiasasi terdiri dari 4 subskala yang diadopsi dari (Gronewold dan Donle,2007) yaitu bantuan ketika kesalahan terjadi yang diukur dengan 3 item, subskala analisa kesalahan yang diukur dengan 5 item, subskala komunikasi kesalahan yang diukur dengan 5 item dan subskala perbaikan kesalahan yang diukur dengan 2 item. Orientasi kesalahan individu terdiri dari 4 subskala yang diadopsi dari (Gronewold dan Donle,2007) yaitu komunikasi kesalahan yang diukur dengan 3 item, subskala analisa kesalahan yang terjadi yang diukur dengan 5 item, subskala belajar dari kesalahan yang diukur dengan 3 item dan subskala kompetensi dalam menghadapi kesalahan yang diukur dengan 2 item. Kedua konstruk dimasing masing item tersebut diukur berdasarkan lima point skala likert, (1) tidak diterapkan sama sekali sampai (5) diterapkan secara penuh. Pada dua variabel ini pengukuran terlebih dahulu dilakukan pengkodean kembali (reverse code) untuk menyesuaikan dengan kondisi alamiah variabel, sehingga angka indikator yang semakin rendah menunjukan tingkat iklim organisasi yang semakin terbuka dan tingkat orientasi kesalahan individu yang semakin terbuka.. Total 15 indikator mengukur iklim kesalahan organisasi memiliki nilai alpha ( $\alpha$ cronbach : 0.948) dan 12 indikator orientasi kesalahan individu memiliki nilai alpha $(\alpha$ cronbach : 0.964). Penanganan kesalahan individu terdiri dari 2 subskala yang diadopsi dari (Gronewold dan Donle,2007) yaitu umpan balik tulisan yang diukur dengan 6 item, dan subskala umpan balik oral yang diukur dengan 6 item. Masing masing item tersebut akan diukur berdasarkan lima point skala likert, (1) sangat jarang sampai (5) sangat sering. Indikator yang semakin tinggi menunjukan penganganan kesalahan yang mengarah pada pencegahan kesalahan sebaliknya, semakin rendah mengarah pada manajemen kesalahan. Total 15 indikator mengukur penganganan kesalahan memiliki nilai alpha $(\alpha$ cronbach : 0.739). Auditor tenure 
diukur dengan item tunggal yaitu Apakah anda sering mengaudit department / kantor yang sama dengan tiga pilihan jawaban (1) beberapa kali dalam setahun, (2) sekali setahun (3) setiap 2-3 tahun.

\section{Sampel penelitian}

Sampel penelitian ini diperoleh dengan menggunakan teknik convenience sampling, Kuesioner disebar dengan mendatangi langsung kantor-kantor auditor inspektorat kementerian. Total jumlah kusioner yang disebarkan pada penelitian ini sebanyak 150 kepada auditor pemerintah, dimana hanya sebanyak 122 kuisioner yang berhasil dikumpulkan kembali, setelah melalui proses seleksi dengan mengeluarkan kuisioner dengan jawaban yang kosong dan dengan jawaban yang meragukan diperoleh sebanyak 103 kuisioner yang layak untuk digunakan,maka dari data tersebut penelitian ini memiliki total tingkat pengembalian (response rate $95.3 \%$ ). Mayoritas responden yang dikumpulkan adalah wanita sebanyak 105 responden atau $73.43 \%$, berdasarkan usia diketahui mayoritas responden berusia antara 18-22 tahun sebanyak 90 orang atau $90 \%$, diikuti kelompok usia antara 23-27 tahun sebanyak 8 orang atau $8 \%$, dan terakhir sebanyak 2 responden atau 2 $\%$ tidak mengisi kolom usia. Berdasarkan pengalaman sampel yang diperoleh dalam penelitian ini mayoritas adalah memiliki pengalaman lebih dari 5 tahun sebesar 47 orang atau $45.63 \%$, lalu kelompok dari Lainnya Berdasarkan kategori pendidikan mayoritas responden menempuh pendidikan terahkir S1 sebesar 54 orang atau $52.43 \%$, lalu diikuti oleh kategori S2 sebesar 36 orang atau $34.95 \% \%$ dan yang paling kecil adalah kelompok Diploma sebesar 13 orang atau $12.62 \%$

\section{HASIL DAN PEMBAHASAN}

Untuk menjawab hipotesa 1-3 Setelah melihat hasil analisis deskriptif dari masing-masing variabel pembahasan selanjutnya adalah menginterpretasikan hasil uji analisi regresi linear berganda. Analisis ini digunakan untuk membuktikan hipotesis yang telah dibuat pada bagian awal yaitu peran moderasi auditor tenure. Pembahasan selanjutnya adalah menginterpretasikan hasil uji analisis Moderated Regression Analysis (MRA) dengan uji interaksi, sebagai penentu variable moderator. Pada sub bab ini, kita akan melihat pengaruh variabel-variabel terikat (dependent) yang digunakan dalam penelitian terhadap variabel bebasnya (independent), dimana berdasarkan perumusan yang dibuat uji regresi linear ini adalah :

$$
\begin{aligned}
& \mathrm{Y}=\mathrm{a}+\mathrm{b}_{1} \mathrm{IKO}+\mathrm{b}_{2} \mathrm{OKI}+\mathrm{e} \\
& \mathrm{Y}=\mathrm{a}+\mathrm{b}_{1} \mathrm{IKO}+\mathrm{b}_{2} \mathrm{OKI}+\mathrm{b}_{3} \mathrm{OKI} \text { xAT }+\mathrm{e}
\end{aligned}
$$

Tabel 1. Hasil Uji Regresi Linear berganda 


\begin{tabular}{|c|c|c|c|c|c|c|}
\hline \multirow[t]{2}{*}{ Variabel } & \multicolumn{3}{|c|}{ Persamaan 1} & \multicolumn{3}{|c|}{ Persamaan 2} \\
\hline & $\beta$ & $t$ & Sig.t & $\beta$ & $T$ & Sig.t \\
\hline Iklim kesalahan organisasional & 0.213 & 3.225 & 0.002 & 0.218 & 3.280 & 0.001 \\
\hline Orientasi kesalahan individu & 0.149 & 2.638 & 0.010 & 0.194 & 2.500 & 0.014 \\
\hline OKIxAT (moderator) & & & & -0.026 & -0.856 & 0.394 \\
\hline Konstanta & 2.237 & & & 2.229 & & \\
\hline $\mathrm{R}$ & 0.426 & & & 0.433 & & \\
\hline $\mathrm{R}^{2}$ & 0.182 & & & 0.188 & & \\
\hline $\operatorname{Adj} R^{2}$ & 0.165 & & & 0.163 & & \\
\hline $\mathrm{F}$ & 11.108 & & & 7.629 & & \\
\hline Sig_F & 0.000 & & & 0.000 & & \\
\hline
\end{tabular}

Dependen variabel : Penanganan kesalahan

Berdasarkan table 1 diketahui bahwa pada persamaan 1 korelasi dari nilai observasi dan nilai prediksi dari variabel terikat sebesar $42.6 \%(\mathrm{R}=$ 0.426), ini menunjukan korelasi tersebut berada pada tahap substansial. Nilai $\mathrm{R}^{2}$ menunjukan nilai 0.182 atau $18.2 \%$, ini artinya bahwa variabelvariabel bebas dalam penelitian ini yaitu, Iklim kesalahan organisasional, dan orientasi kesalahan individu hanya mampu menjelaskan sebesar $18.2 \%$ variasi perubahan Penanganan kesalahan pada auditor di DKI Jakarta. Berdasarkan hasil uji $\mathrm{F}$ disimpulkan bahwa Ho ditolak dan Hi diterima, hal ini karena dan nilai signifikansi $F$ yang lebih kecil dari $0,05(\mathrm{~F}=11.108$; $0.000<\mathrm{p}: 0.05)$. Dengan demikian dapat dikatakan bahwa model prediksi penanganan kesalahan auditor dengan menggunakan predictor Iklim kesalahan organisasional, dan orientasi kesalahan individu, adalah model yang valid secara statistik

\section{Iklim kesalahan organisasional}

Berdasarkan hasil pada persamaan 1 di table 1 Variabel Iklim kesalahan organisasional, berdasarkan perhitungan diperoleh $(\beta 1=0.213$ $\mathrm{p}=0.002<0.05)$ maka disimpulkan Iklim kesalahan organisasional berpengaruh positif signifikan terhadap penanganan kesalahan oleh auditor dan $\mathrm{H}_{1}$ diterima. Indikasi ini menunjukan bahwa semakin tinggi keterbukaan dalam iklim kesalahan organisasi maka semakin tinggi penerapan penanganan kesalahan melalui strategi manajemen kesalahan setiap peningkat 1 point persepsi iklim kesalahan organisasi maka akan meningkatkan sebesar 0.213 kecenderungan Penanganan kesalahan dengan strategi manajemen kesalahan.

\section{Orientasi kesalahan individu}

Berdasarkan hasil pada persamaan 1 di table 1 Variabel Orientasi kesalahan individu, berdasarkan perhitungan diperoleh $(\beta 2$ $=0.149 \mathrm{p}=0.010<0.05) \quad$ maka disimpulkan Orientasi kesalahan individu berpengaruh positif signifikan terhadap penanganan kesalahan oleh auditor dan $\mathrm{H}_{2}$ diterima. Indikasi ini menunjukan bahwa semakin tinggi keterbukaan 
dalam Orientasi kesalahan individu maka semakin tinggi penerapan penanganan kesalahan melalui strategi manajemen kesalahan setiap peningkat 1 point persepsi Orientasi kesalahan individu maka akan meningkatkan sebesar $\quad 0.149$ kecenderungan Penanganan kesalahan dengan strategi manajemen kesalahan.

\section{Moderasi audit tenure}

Berdasarkan hasil pada persamaan 2 di table 1 Variabel moderasi yaitu interaksi antara Orientasi kesalahan individu dan audit tenure, berdasarkan perhitungan diperoleh $(\beta 2=-0.026 p=0.394>0.05)$ maka disimpulkan audit tenure tidak memoderasi pengaruh Orientasi kesalahan individu terhadap penanganan kesalahan oleh auditor dan $\mathrm{H}_{3}$ ditolak. Indikasi ini menunjukan lama hubungan antara auditor dengan organisasi tidak mempengaruhi besar kecilnya pengaruh keterbukaan dalam Orientasi kesalahan individu terhadap penerapan penanganan kesalahan melalui strategi manajemen kesalahan.

\section{SIMPULAN,KETERBATASAN DAN KONTRIBUSI PRAKTIS}

\section{Simpulan}

Penelitian ini bertujuan untuk mengetahui pengaruh Iklim kesalahan organisasional, dan orientasi kesalahan individu terhadap penanganan kesalahan pada auditor Inspektorat Kementerian. Temuan pertama penelitian menunjukan bahwa iklim kesalahan organisasional berpengaruh positif signifikan terhadap penangan kesalahan auditor. Hasil ini sejalan dengan temuan
Gronewold dan Donle (2011) Hasil ini menunjukan bahwa budaya organisasi berperan besar terhadap perilaku karyawan dalam bertindak secara spesifik dalam konteks penelitian ini adalah budaya bagaimana suatu organisasi memandang suatu masalah akan mengarah pada penanganan dengan bentuk manajemen kesalahan. Organisasi yang berhasil melakukan transfer pengetahuan antar anggota adalah organisasi yang individuindividu merasa memiliki kecerdasan bersama, organisasi yang menyakini bahwa tetap terdapat peluang untuk terjadinya kesalahan meskipun pekerjaan telah dilaksanakan dengan baik. Kemudian organisasi yang karyawan diminta untuk belajar tentang segala sesuatu bentuk kesalahan yang dibuat, serta organisasi yang individu-individu dapat dengan bebas meminta pendapat dan bantuan orang lain untuk mengatasi kesalahan yang terjadi, dimana tidak lagi terjadi kerahasiaan atau subjek-subjek yang tidak didiskusikan (Gronewold dan Donle,2007) orang akan semakin menerima dan terbuka terhadap kesalahan, yang mampu menciptakan sikap positif atas kesalahan yang diterjemahkan dalam perilaku auditor yang berusaha untuk mengatasi dan belajar dari temuan kesalahan dari klien.

$\begin{array}{crr}\begin{array}{c}\text { Temuan } \\ \text { menunjukan }\end{array} & \begin{array}{c}\text { kedua } \\ \text { bahwa }\end{array} & \begin{array}{r}\text { penelitian } \\ \text { orientasi }\end{array}\end{array}$ kesalahan individu berpengaruh positif signifikan terhadap penangan kesalahan auditor. Hasil ini sejalan dengan temuan Gronewold dan Donle (2011). Indikasi hasil temuan ini menunjukan bahwa semakin terbuka orientasi individu auditor terhadap 
kesalahan maka auditor akan cenderung menggunakan stratategi penanganan kesalahan berbasis manajemen kesalahan. Hasil ini menunjukan bahwa sikap dan nilai individu auditor berperan besar terhadap perilaku lanjutan dalam melaksanakan pekerjaan. Auditor yang terbuka terhadap kesalahan akan berupaya terbuka untuk mendapatkan umpan balik dan tidak berkonsentrasi untuk mengindentifikasi individuindividu yang bertangung jawab terhadap kesalahan tersebut akan tetapi dengan menganalisa penyebab sistematis dari kesalahan tersebut. Sehingga auditee mampu untuk mendeteksi dan memperbaiki kesalahannya sendiri dan menghindari pengulangan kesalahan tersebut dimasa yang akan datang yang adalah dengan membentuk perilaku subjektif individu auditor yang memandang masalah sebagai hal positif dan sebagai peluang pembelajaran kedepan (Gronewold dan Donle,2007).

Terakhir penelitian ini tidak menemukan bukti empiris peran moderasi audit tenure pada pengaruh orientasi kesalahan individu terhadap penangan kesalahan auditor. Hasil ini menunjukan bahwa keterbukaan komunikasi dari auditor yang bukan merupakan fungsi lama hubungan antara auditor dengan organisasi yang di audit. Indikasi ini menunjukan bahwa nilai keterbukaan pada kesalahan adalah fungsi nilai yang terbentuk sebelum auditor melakukan interaksi dengan organisasi yang akan diaudit, sehingga konsekuensinya pembentukan sikap dan nilai individu akan kesalahan pra audit pada suatu organisasi merupakan modal interpersonal bawaan diluar faktor lama interaksi.

\section{Keterbatasan}

Penelitian ini belum melihat beberapa faktor yang menjadi indikator kualitas audit lainnya seperti faktor spesialisasi pada suatu industri atau departemen, dan pengaruh kepuasan komunikasi antara auditor auditee, dalam memahami pemanfaatan strategi manajemen kesalahan. Penelitian ini juga memiliki beberapa kelemahan yaitu belum diselidikinya hubungan kausalitas antara iklim kesalahan organisasi dengan orientasi kesalahan individu, serta penelitian ini hanya terbatas dari organisasi pemerintahan sehingga belum mampu memberikan generalisasi hasil terhadap organisasi audit lain. Penelitian ke depan dapat menyelidiki faktor kualitas audit lainnya dalam memprediksi faktor pemanfaatan strategi manajemen kesalahan oleh auditor, serta dapat menyelidiki hubungan kausalitas antara dua predictor tersebut untuk dapat memperjelas bentuk hubungan mediasi dan menggunakan organisasi auditor yang lebih beragam.

\section{DAFTAR PUSTAKA}

Asian Development Bank. 2008. Auditing the Lessons Architecture. Operations Evaluation Department Asian Development Bank vol 1 no 32.

BPK. 2006. Rekapitulasi Pemantauan tindak lanjut atas hasil pemeriksaan LKPP pada tahun 2004 dan 2005. Badan 
Pemeriksa Keuangan Republik Indonesia

Cerveny Corinna., Villegas Martha., 2004. "Is Communication a Moderator of the Relationship Between Job Satisfaction and Absenteeism?".

Gold, A. Gronewold, U. dan Salterio, E. 2011. Error management in public accounting firms: Error climate, type and originator. Working paper VU University Amsterdam

Goris, J. R., Vaught, C. B., Pettit, D.J. 2000. Effects of Communication Direction on Job Performance and Satisfaction. A Moderated Regression Analysis " The Journal of Business Communication, Vol. 37,4,348368. Business Source Primer.

Gronewold, U., Gold,A dan S. Salterio. 2011. Reporting Discovered Errors: The Impact of Error-Management Climate and Error Type. Working paper.

Gronewold, U., and M. Donle. 2007. Auditors' Error Handling, Error Orientation, and Audit Organizations' Error Climate -Validity and Reliability of a Measurement Instrument. Working paper

Gronewold, U.dan M. Donle. 2012. Organizational error climate and auditors' predispositions toward handling errors. Behavioral Research in Accounting. Forthcoming.

Handoko, T. Hani. 1995. "Manajemen Personalia dan
Sumber Daya Manusia”. Edisi

Kedua. Yogyakarta: BPFEYogyakarta.

Hansen Don R., and Maryanne M. Mowen, 2003," Management Accounting" $\quad 6^{\text {th }}$ edition. Cincinnati: South Western College Publishing.

Long. Andrew F. \& Harrison. Stephen., 1987. " Health Services Performance". (New Hampshire : Croom Helm). p. 6.

Nitisemito, Alex, S. 1996. “Manajemen Personalia”. edisi ketiga. Jakarta. Penerbit: Ghalia Indonesia

Nymark Søren.2002. Value-based management in learning organizations through 'hard' and 'soft' managerial approaches: The case of Hewlett-Packard.

DRUID

Working Paper No 00-10

Porporato Marcell., 2006 "Impact of Management Control Systems' Intensity of Use on Joint Venture's Performance: an Empirical Assessment", Journal of Management Control System. Vol 21: p. 512-562

Rappaport, A. 1999. New Thinking on How to Link Executive Pay to Performance. Harvard Business Review (marchApril): 91-101.

Robert N. Anthony, and Vijay Govindarajan. 2004.

"Management Control System". 11 Edition. New York: Irwin/Mc. Graw Hill.

Thérin François. 2002. Learning Organization and Innovation 
Performance in High-Tech Small Firms. International Council for Small Business 47th World Conference.

Zhang Man dan McCullough James, 2001 Effect of Learning and Information

TechnologyCapability on Business

Performance.Washington State University, USA 